\title{
2
}

\section{The Mana of Kū: Indigenous Nationhood, Masculinity and Authority in Hawai'i}

\author{
Ty P. Kāwika Tengan
}

A long time ago, the god Kü lived in Hawai'i as a human. When a famine brought his family to the brink of starvation, he told his wife that he could save them only if he went on a journey from which he could not return. At first she refused but then finally consented when she heard the cries of their hungry children. Kū then stood on his head and disappeared into the earth. The woman's tears watered that spot, and from it grew the 'ulu (breadfruit) tree whose fruits saved all the people (Pukui with Green 1995: 8).

In 2008, Bernice Pauahi Bishop Museum (Bishop Museum) project director Noelle Kahanu wept as she stood before a seven-and-a-halffoot tall carved wooden ki'i (image) of Kū that was a part of a Polynesian exhibit at the Musée du Quai Branly in Paris, France (Jolly 2011: 125; White 2010). This ki'i, on loan from the British Museum in London, was one of only three temple images of Kū (all carved from breadfruit) that survived the 1819 dismantling of the Hawaiian precolonial state religion known as the 'aikapu; the other two images resided at the Bishop Museum in Honolulu and the Peabody Essex Museum (PEM) in Salem, Massachusetts. Speaking at the 'Exhibiting Polynesia: Past, Present, and Future' symposium at Quai Branly, Kahanu pondered the 
significance of reuniting the three Kū images: 'We dream that they will once again stand together and that which is separated by oceans shall be united' (Kahanu 2012).

In 2010, on the bicentennial of Kamehameha's unification of the Hawaiian Kingdom, the three Ku stood together for four months at the Bishop Museum in a historic exhibit entitled E Kū Ana Ka Paia: Unification, Responsibility, and the Kü Images. The Hawaiian title, which translates to 'The Wall Will Stand', came from a prophecy chant dating to the time of Kamehameha. Kahanu, who organised and curated the exhibit, had spoken of this prophecy when she was at Quai Branly two years prior. Speaking in 2010 on a Native Hawaiian radio talk show, she explained:

It's said that [the prophet Kapihe] predicted this overturning, the ending of the 'aikapu and the coming of a new religious system ... In today's context, it really represents a kind of an overturning of social and political order and a reemergence of Hawaiian nationhood and solidarity. And it's really I think in that context that this exhibit fits ... for what it means to come together as a people. (Kahanu 2010)

Indeed, over 71,300 visitors (65 per cent of whom were residents) came together at the museum between June and October, including numerous Hawaiian cultural organisations that gave offerings of chants, dances and the fruits of the land (Bishop Museum 2010: 2). The second 'Aha Kāne Native Hawaiian Men's Health Conference held its opening ceremonies in the presence of the Kū, seeking to draw inspiration from the deity of male generative power. In their end of the year report, the Bishop Museum featured an anonymous comment left in the guest book that read, 'That may be the true mana of $K \bar{u}$, to bring together from there, to bridge differences, to impress, to educate, to inspire, to unite us all!' (Bishop Museum 2010: 2).

As a member of the community consultant team and as the humanities scholar for the exhibit, I was both participant in and witness to the cultural, social and political workings of calling forth the 'mana of $\mathrm{Ku}$ ' (or 'mana $\mathrm{Ku}$ ', as it was sometimes referred to). Not surprisingly, these towering 800-pound wood carvings became focal points for talking about mana, a term that people defined in a variety of ways that included 'spiritual power' (Enomoto 2010), 'belonging' (Grace 2010), and 'status' (Nākānelua 2010). Even when people were 
not using the term directly, talk of supernatural agency, spectacular accomplishment, and Indigenous empowerment all highlighted the continued significance of mana in contemporary Hawaiian society.

For the remainder of this chapter, I will reflect on the experiences and conversations I was involved in to explore the ways that mana figured into discourses of and struggles over Native Hawaiian nationhood, masculinity and authority. I argue that invocations of mana as both essence and practice reflect strategies for asserting Indigenous continuity despite and through historical, political and cultural transformations. Here I highlight the ethical, aesthetic and political dimensions of remaking Indigenous masculinities as a form of mana Kū. The exhibit and related events also offer insights into the possibilities and limitations of thinking about the role of mana in the reshaping of relationships between Native peoples, anthropologists and museums (Clifford 2013).

\section{The departure of Kū}

Kū, one of the four major male deities (along with Lono, Kāne and Kanaloa) in the Hawaiian pantheon, is most famously (and reductively) known as 'the god of war'. In actuality, the martial aspect was only one of many attributed to this deity. Broadly speaking, Ku is the deity of male generative power who is frequently paired with his female counterpart Hina. The most famous manifestation of Kū is Kūkā'ilimoku, the island-snatching Kū that Kamehameha inherited from his uncle and used to legitimate his campaign of conquest in the late eighteenth and early nineteenth century.

The precise origin of these three images in particular, and how they ended up leaving Hawai' $i$, is somewhat unclear. The English missionary William Ellis who was touring the islands in 1823 observed three ki'i still standing at Ahu'ena, a temple Kamehameha restored and rededicated to Lono at his final residence and first Capital of Kamakahonu in Kona (Tengan and Roy 2014). At the time Ellis was making his tour of Hawai'i Island, Governor Kuakini had converted the heiau into a fort, where the ki'i stood 'like sentinels amidst the guns' (Ellis 1825: 323). As Kahanu stated on an interview for a local television station, 'That gathering of three images has not been seen by human eyes since that time' (Hyden 2010). 
And indeed, up until the last few months before the exhibit was held, it was unknown whether or not they would be seen together. Recalling her talk at Quai Branly in 2008, Kahanu described a 'miracle of miracles' when Lissant Bolton, who was curator of the Pacific Collection of the British Museum and in the audience, told her an international loan was possible (Kahanu 2012). Yet concerns among the loaning institutions remained, in part due to the fact that PEM's director Dan Monroe had been a member of the NAGPRA (Native American Graves Protection and Repatriation Act) Review Committee that handled the Kawaihae (a.k.a. Forbes Cave) case that divided the Hawaiian community deeply (and publicly) in a dispute over ki'i that came from a burial cave on Hawai'i Island (Johnson 2011). There were fears that the Kū images would become the focus of a new and pitched repatriation battle over the authority of museums to own and control Hawaiian culture.

Within the Hawaiian community, important ethical concerns arose. In order to ensure that the proper cultural and social protocols were followed, Kahanu gathered a team of community consultants comprised of cultural experts. Kahanu's memory of these discussions matches mine: 'You have an older, more conservative Hawaiian group that were fearful. So, what happens when the three come together? What about the mana, or energy that might be re-animated? ... Who's responsible if you awaken something? ... These are really, really big concerns' (Kahanu 2012). Men in the consultant group who were versed in rituals related to $\mathrm{Ku}$ agreed to take on the kuleana (responsibility) of developing the proper protocols and procedures for bringing the ki'i to Hawai' $i$, receiving the offerings during the exhibit, and returning the ki'i back. Indeed, most of the consultants were anticipating that Kù would awaken, and with him the Hawaiian people.

Less than six months before the exhibit was to open, all of the museums were finally on board. However, now the primary obstacle was the lack of funds. At the last minute, the Office of Hawaiian Affairs came through with a \$US100,000 grant. Kahanu recalled:

So, you know, to me, it's sort of like, um, they [the Kū images] chose to come. In other words, there's only so much people can do to make something happen. And at some point there is a higher plane of involvement ... [Y]ou put your words out there ... and at some point they're engaged, they hear the call, they decide that they want to be here, and then they facilitate the process of ultimately getting here. That's my only explanation. (Kahanu 2012) 
It is hard to describe this as anything less than a manifestation of mana. As Sahlins has put it (1981: 31):

Yet, again, one is in the presence of something familiarly Hawaiian: a structure of the long run-mana. Perhaps most essentially, mana is the creative power Hawaiians describe as making visible what is invisible, causing things to be seen, which is the same as making them known or giving them form.

\section{The return of Kū}

Two weeks before the exhibit, a team made up of Bishop Museum staff and members of the Hale Mua Native Hawaiian Men's group embarked on a journey to Salem and London to ensure that the Ku images were properly and ceremoniously readied for their return to Hawai'i. As I have written elsewhere (Tengan 2008), the Hale Mua was formed as an organisation for Hawaiian men to reconnect with their history and culture, primarily through the practice of warrior art forms and ceremonies, and to forge bonds of communion and support that would enable them to be leaders in their families and communities. In particular, this responded to a pervasive discourse of Hawaiian emasculation - the perception that Hawaiian men had become ineffectual as women came to take on the dominant roles in the home and the nation. This process has also been understood metaphorically and literally as the loss of Kù and his mana; the return of Kū would likewise symbolise the restoration of 'Ōiwi men's identities and kuleana. As Kyle Nākānelua, head of the Hale Mua, explained to me in 1999:

Because we're a male, masculine oriented group, our 'imi 'ana (searching) is towards the masculinity of the culture because there's been so much femininity ... [I]f you believe, everything has its place and time, then it should hold true to da fact that there should be a place and a time for the mana Kū. There's a time for healing, there's a time for building mana. (Tengan 2008: 144)

Yet since, as Jolly notes, 'male potency emerges in relation-and sometimes in resistance - to the hegemonic forces of colonialism and contending imperial models of masculinity' (Jolly 2008: 1), invocations of mana $\mathrm{Ku}$ can potentially reinforce structures of settler heteropatriarchy (Morgensen 2011). Thus the selection of the 
consultant group and the delegation was also scrutinised, to which Kahanu responded by citing the significance of returning the kuleana of Kū to the men who had trained for it.

The 'search' for the mana of Kü - here indexing Hawaiian male potency and generative power - came full circle for Nākānelua when he was selected to be a part of the Bishop Museum delegation in 2010. He kept a journal of the trip, detailing the signs in the heavens and challenges on earth they encountered. At a particularly trying time in London, he wrote about the need to continue with his daily 'ho'omana' (prayer, ritual, worship; literally 'to create mana'):

Must go through the rituals anyway. It is about affirming who we are and the conduct that is necessary for us to perpetuate our duties and responsibilities. ... This whole journey is about affirming ourselves as a people in relationship to our ancestors that have gone before us. The ritual allows us to commune with that way of being. (Nākānelua 2010: 3)

Indeed, much the same could be said about the journeys of all Hawaiians who have sought to revitalise mana as a central component of healing, decolonising, and rebuilding nation (Marshall 2011).

Despite all of the hardships and challenges, the exhibition $E K \bar{u}$ Ana Ka Paia was successfully opened on 4 June 2010. Speaking on a panel discussion after he officiated at the opening ceremonies, tattoo and hula master and community consultant Keone Nunes addressed any of the lingering fears that some might have in the Hawaiian community:

When you go in there, you don't feel that you're fearful for your life, but you can feel the mana of these images in a very welcoming way, in a very heartfelt way ... There's a lot of things that it can represent for each and every one of us ... who come and see these images for something that is beyond the carved image, beyond the wood. But you see the mana of these images. (Nunes 2010)

\section{Aesthetics of mana}

As Nunes' comment suggests, the exhibit led to an intense meditation on and redefinition of the aesthetics of mana. The Honolulu StarBulletin quoted Peabody Essex Museum director and CEO Dan Monroe stating that 'the statues are "masterpieces which reflect the artistic 
genius of native Hawaiians"' (Gee 2010). While such praise is certainly deserved, it is also limiting in its focus on 'masterpieces' and 'artistic genius'. As Herman Pi'ikea Clark explains:

In contrast to European art, which evolved to become an autonomous and socially detached class of objects and images produced principally for aesthetic engagement ... the objects and images created in a Kanaka Maoli cultural context were designed to function as components within an integrated social, religious, governmental and economic system ... In this setting, Kanaka Maoli visual culture served as visual signifiers, utilitarian tools and repositories of genealogical narrative and cultural knowledge. (Clark 2011: 139)

In specific relation to ki'i, he comments:

the repetitive features carved onto a temple idol, though contributing to the object's aesthetic quality and appearance, also served as a mnemonic feature to aid in the recall of information to those who had the capacity to read its design. (Clark 2006: 12)

Much of the challenge for the contemporary Kanaka 'Ōiwi community was in fact how to 'read' the designs that were unfamiliar to many. One of the unique features of the ki'i from the British Museum was the presence of what appeared to be dozens of tiny faces carved into the long headdress (or hair) that extends down to the base. Various interpretations were put out, including the thought that it might be the face of a dog (which was a body form of Kū).

Rather than see this lack of knowledge as a shortcoming, it might instead be viewed as an opportunity for reconnection and recreation of culture and mana. The Kanaka Maoli artist Kalamakūloa (David He'akoelekauaikalani Kalama Jr), whose work was featured in the exhibit's brochure next to my essay, spent 54 days at the museum drawing charcoal sketches of the ki'i from various angles (Figure 8) (Dawrs 2011). In the process, he witnessed large and small ceremonies that were conducted as community members laid offerings before $K \bar{u}$, and he himself came to be an individual/activity to be viewed and interacted with by visitors and news crews. On his website moku mana, which he translates as 'power island' (Kalama Productions Inc. 2010-11), he created a page entitled 'Makaku' as an online space for communing with the ki'i and others who forged meaningful connections to Kū. ${ }^{1}$ On it was

1 More recent work can also be found on David He'akoelekauaikalani Kalama Jr n.d. Kalamakūloa. Online: www.kalamakuloa.com/Aloha.html (accessed 7 October 2015). 
a slideshow of his sketches, a YouTube video he created entitled 'Ki' $\mathrm{i}$ Akua - 54 Nights with Kū' (Kalamakūloa 2011b), and a link to purchase his ebook of the same name (Kalamakūloa 201 la). In the book Ki' $i$ Akua - 54 Nights with Kū Kalamakūloa provides an analysis of the 'Kona Style' that the ki'i were carved in:

What also makes the 'Kona Style' significant is the 'waha' complexthe jaw, mouth, tongue.

Words are alive in our tradition. They can bring and take away. Words have mana.

What if the waha, the mouth, is the central motive of the entire sculpture? As the focus point it accepts the counter-point of the arching headdress complex, with the nose as leading focus, and repeated with the pectoral chest. Metaphors, symbolism, animism ... These structural themes are rendered with meticulous and often symmetrical precision. (Kalamakūloa 2011a, Locations 235-36)

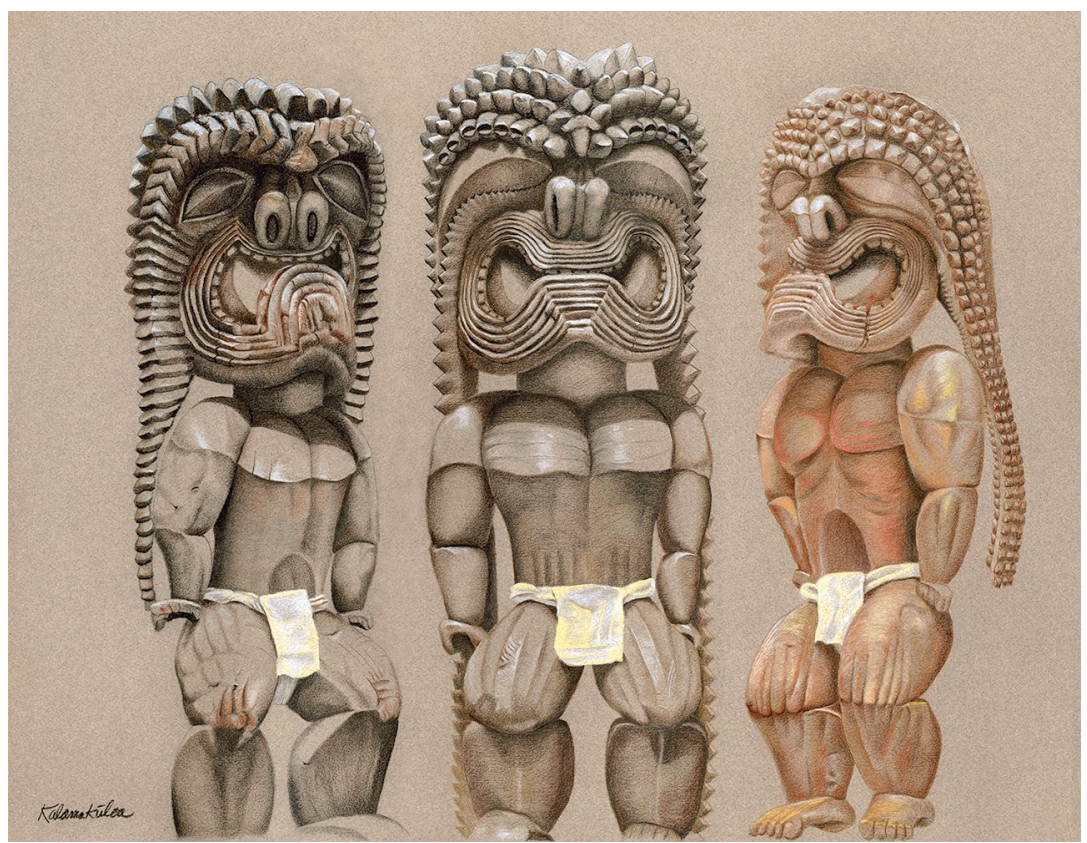

Figure 8. Kūkolu Aka Mahina by Kalamakūloa.

Source: Used with permission of artist. 
Kalamakūloa's analysis calls up the explicit linkages between speech, voice and power that Noenoe K. Silva notes in her readings of the shifting meanings of 'mana' in the nineteenth-century Hawaiian Kingdom (see Silva, this volume). Like Silva, Kalamakūloa underlines the contemporary significance of renewed understandings:

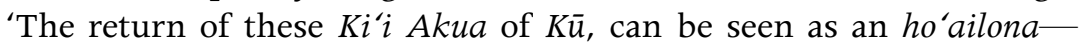
an omen, a message from the ancestors. The $K{ }^{\prime} i$ iare portals to connect to the Life Force, where we can commune with the Divine Energy, our ancestors, our past and the future' (Kalamakūloa 2011a, Location 321). As with other Kanaka 'Ōiwi artists, performers, scholars and educators, his work draws on ancestral patterns to channel new mana to future generations (Clark 2011).

Two weeks after the exhibit opened, the 'Aha Kāne Native Hawaiian Men's Health conference held its opening ceremonies at the Bishop Museum. The second such conference since 2006, the 'Aha Kāne was in many ways an extension of the project of the Hale Mua out to a broader constituency of Hawaiian men. Billy Kahalepuna Richards, board member of the 'Aha Kāne as well as communications director at the Partners in Development Foundations, a Vietnam Veteran (Marine), lua master, and community consultant for the Kū Exhibit, recalled, 'I think the combined mana of those who participated in the opening lifted that particular 'Aha Kāne to another level' (Richards 2012). Thomas Ka'auwai Kaulukukui Jr, a keynote speaker at the 'Aha Kāne, board chairman of the Queen Lili'uokalani Trust, a former judge, Vietnam Veteran (Army paratrooper), lua master, and consultant, spelled out the ways in which veterans who had gone through the lua martial arts training or participated in the 'Aha Kāne came to a deeper understanding of their Hawaiian warrior identity:

For me and for most who have had military training, lua training is an affirmation that warriorhood, which we experience in the American military, is part of our DNA ... For most of us, it transforms our lives ... Enormously powerful. The 'Aha Kāne is another means of doing that, for males looking into male responsibility ... And maybe that aspect of the Kū personality, if you want to call it, for those of us who are veterans illustrates most clearly than anything else you could learn, about the tie between your Hawaiianness, and your DNA, and that aspect of your mana, and your skill. (Kaulukukui 2012) 
For Richards, who had consciously adopted Kū as his god when he went to Vietnam, the Kū exhibit and the 'Aha Kāne was a reconnection in a different way. When it was time for the two Kū images to go back, his brother-in-law Kyle Nākānelua was unable to make the return trip. At first Richards did not feel it was right for him to take Nākānelua's place, but his wife Debbie Nākānelua Richards told him, 'Kū took you through war. Maybe it's time to thank him' (Peabody Essex Museum 2010). It was thus that Richards closed the circle with ceremony (see also Tengan 2015).

\section{The art of re-membering}

Did I forget to mention that the Kū image is literally dis-membered? Speaking at the opening panel named 'Nā Maka o Kū' ('The Many Faces of $\left.\mathrm{Ku}^{\prime}\right){ }^{2}$ Nunes explained to the audience that sometime after the end of the 'aikapu in 1819 when the temple images were being torn down and burned, someone (perhaps Hawaiian, perhaps not) broke off the ule (penis) of the ki'i that now resided at the Bishop Museum (see also Ganaden 2014). While this was a pattern found among other male images, the ule of the other two ki'i from London and Salem were still intact. The occasion of bringing all three ki' $i$ together renewed ongoing discussions and negotiations that Nunes had been having for years with the Bishop Museum regarding the restoration of Kū. Comparing it with Michelangelo's sculpture of David, which was repaired after a man vandalised it in 1991, Nunes asked the audience if our artwork and artist was any less important. If not, he asked, 'why is it that we allow ... the only one we have in Hawai'i to be incomplete, to be emasculated?' The question was as much of a challenge to the museum, whose concerns had to do with curatorial conservation, as it was to the broader Hawaiian community

2 The other panelist was Sam Kaha'i Ka'ai, a kālai ki'i (carver of images), orator, and co-founder with Kyle Nākānelua of the Hale Mua men's group. For more on Ka'ai's important contributions to rethinking aspects of Ku in the Hawaiian movement, as well as his comments at the panel, see Tengan (2014a; 2014b). As I relate elsewhere (Tengan 2008: 83), Sam also discussed another famous dis-membering in Hawaiian history when the high chief Keōuakū'ahu'ula ceremonially cut off the tip of his penis before Kamehameha slew and sacrificed him to Kū at Pu'ukoholā Heiau in 1791. In the context of contemporary efforts to build mana that would bring Hawaiians together and reclaim sovereignty, Keōuakū'ahu'ula was re-membered as leader who sacrificed all in order that his descendants and people may live on into the future, not unlike the story of Ku the breadfruit tree. 
still fearful of the potency of Kū. For Nunes, the castration of the image was a powerful metaphor and metonym for the emasculation of Hawaiian men. The association between image and man was quite literal for him as he argued that the desecration of the ki' $\mathrm{i}$ was one of the main reasons that Hawaiian men had 'been floundering for years and years, because we are not intact' (Nunes 2010). But now with all three ki'i reunited, Nunes found another meaning of the term 'maka' that named his panel: 'a beginning'. ${ }^{3}$ Writing of a similarly powerful exhibition in Kodiak Island (Alaska) that saw the return of ancestral Suqpiaq masks held in France, James Clifford writes of it as 'a restorative connection across time and space. A homecoming and a beginning' (2013: 309). So too did the arrival of Kü herald a renewal of mana for Hawaiian men, who were claiming new agency and authority in matters of cultural representation. Nunes pushed to assert that 'it's a community thing', and that 'if the community says it's necessary to restore Kū to his fullness', it should happen. While Hawaiian men may not have had much of a say in the past, which he related directly to the emasculation of the ki'i, today, as Nunes playfully put it, 'we're starting to grow another pair!' (Nunes 2010).

Four years after the other two Kū returned to the British Museum and the Peabody Essex, the Bishop Museum's ki'i remained incomplete. This, however, did not stop 'Ōiwi artists from finding new and creative ways of 'manning up'. In 2014, Carl F.K. Pao and Solomon Enos collaborated with Drew Broderick to put on a show entitled Pewa II: Remasculation and Human Seed Ships (8 May -8 June) at the contemporary art space of SPF Projects in Honolulu. Pao is known for his larger-than-life carvings of wooden ule. In his 'Artist Statement' (Pao 2014a), which I quote at length here, Pao explains that the emasculation of ki'i with the advent of Christianity:

was performed as a way to remove the mana from these ki'i (actually, most ki'i did not even survive this period, as the majority were destroyed by fire). Another possible reason for the emasculation could have taken place as these ki'i made their way to other shores. Historical accounts reveal the disfiguring of ki'i to make them more appropriate to their new owners by way of trade or purchase.

3 Recall that Makakū is also the name of the page dedicated to Kū on Kalamakūloa's Mokumana site. Online: mokumana.com/MANA/Makaku/Makaku.html (accessed 7 October 2015). 
Understanding all of this got me to wonder if this act of emasculation had any sort of affect on our Hawaiian psyche. Especially, if when you look around at all of the commercial mainstream images appropriating ki'i kupuna [ancestral images], none have ule or penises. And what of all of the cheap or even expensive reproductions? No ule. If ki'i kupuna are to be portraits of our kupuna [ancestors], then what message is this sending? No ule, then no future?

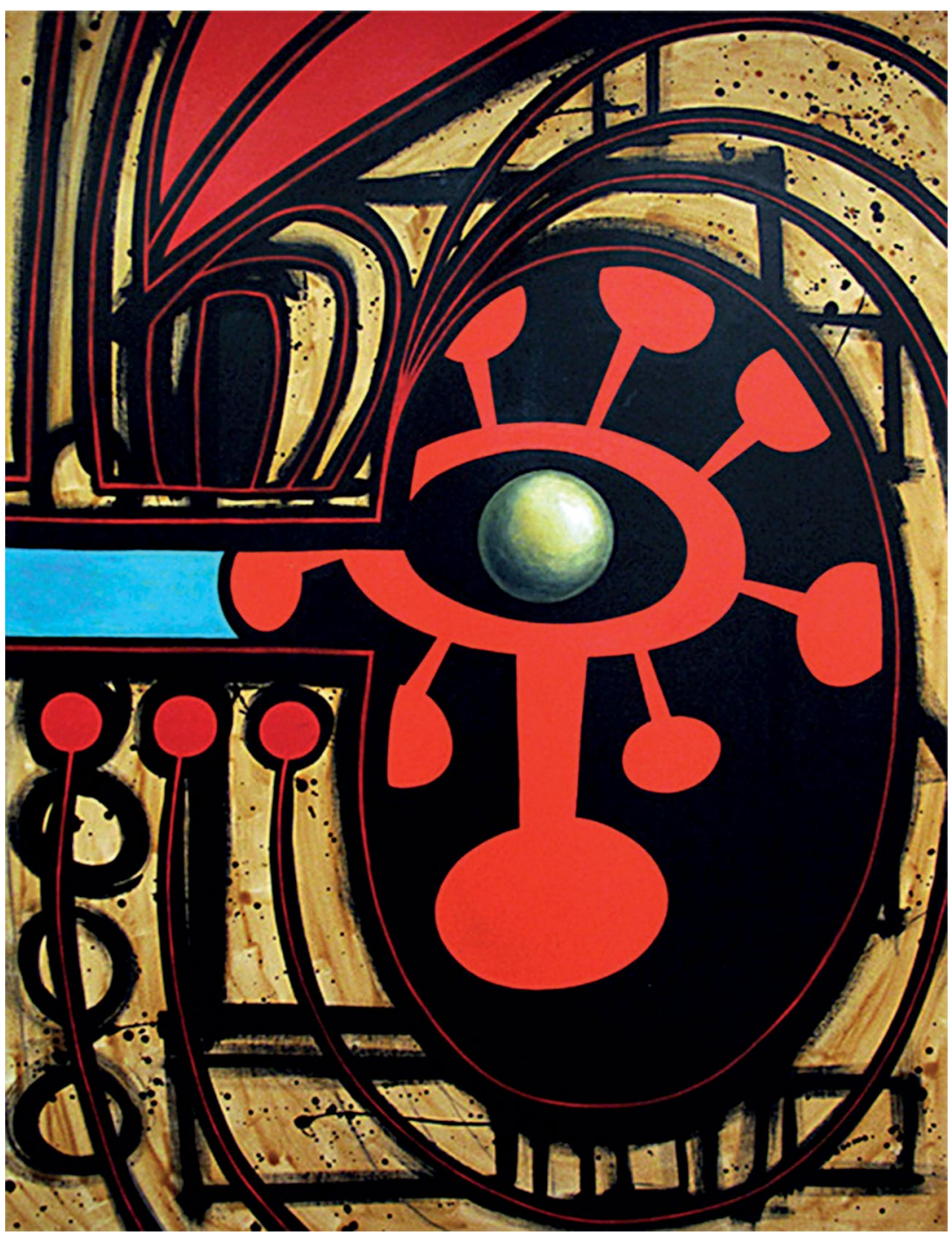

Figure 9. Ki'i Kupuna: Maka.

Source: By Carl F. K. Pao, used with permission of artist. 
Thus his work seeks to restore mana through 'remasculation', which he defines as '[a] process of decolonising, de-indoctrinating, and remembering the importance of the male role in our Hawaiian societal structure and systems. To not re-member and to continue to emasculate the images of our kupuna is only to reassure an imbalance of our people and lāhui [nation] and a continued emasculation of ourselves' (Pao 2014a).

The two-storey space of SPF Projects, formerly a taxi cab garage, featured Pao's Remasculation pieces on the bottom floor. ${ }^{4}$ Walking in from the open garage doorway, one's eyes were drawn immediately to the centre of the room, where stood a 40-inch tall, 12-inch diameter (101.6 cm tall, $30 \mathrm{~cm}$ diameter), black wooden ule with lines and arches of pewa, bow tie-shaped patches of wood inserted along fissures to repair cracks. On the wall in the back of the ule hung a painting entitled $K{ }^{\prime} i$ Kupuna: Maka (see Figure 9). The image depicts a close-up of the face of a ki'i, in particular, half of its nostril and mouth (part of the 'waha complex' that Kalamakūloa mentions above). Yet the focal point is not the mouth itself, but what is in it - an eye peering out, taking the form of the 'masculine element of the flower', especially its 'stamens' (Pao 2014a). On the left wall was a large, brown felt cutout panel of a ki'i of Kù that visitors were invited to approach, blindfolded, and rub on it a red felt ule (like pin the tail on the donkey, but not). Three ule carved from niu (coconut tree wood) between $10-12$ inches $(25.4 \mathrm{~cm}-30 \mathrm{~cm})$ were displayed next to this. Chiselled into the floor were well-endowed petroglyphs 'presented by the Post-Historic Museum of the Possible Aboriginal Hawaiian', whose other artefact was a grill upon which wooden ule of both Indigenous and foreign woods were barbecued. And on the right wall appeared excerpts of text taken (quite improbably) from my research, including the following quote:

4 Enos' Human Seed Ships on the top floor, a continuation of his Polyfantastica work, was comprised of dozens of digital drawings painted on 9" x 12" $(22.9 \mathrm{~cm} \times 30 \mathrm{~cm})$ mailing envelopes that represented a future for Hawaiian productivity and generation as the 'seed' of Hawaiiankind was to be spread across the universe to inseminate new lands. The text on the wall beneath the stairs that went to the second floor was meant to connect the two spaces, as was the smoke from the burnt ule on the grill. 
Bodies figure centrally in the gendered work of decolonization, for it is there that alternative forms of being and acting - in the Hawaiian case, those based in ea (sovereignty, life, breath), mo'okū'auhau (genealogy), and mana (spiritual power and authority) - are re-membered. ${ }^{5}$

In an interview, Pao (2014b) described his aesthetic, which works with complementary colours (usually bright) and surfaces (frequently large), as a 'search for being pono', which is 'to be in balance'. There is also a significant play on kaona (layered meanings), often to humorous effect. His discussion of 'maka' - which means eye, face and stamen all at once (in addition to much more, including the 'beginning' described by Nunes above) - exemplifies what Brandy Nālani McDougall (2014: 1) has called 'kaona as a decolonial aesthetic practice'. Pao (2014b) explained:

Some might argue that politically charged or driven artwork is not necessarily for aesthetic purposes ... and that political art is usually just message driven, and it's not about pretty flowers and trying to capture a moment or anything of beauty; it's more or less just driving a point. But then I guess that's also, for a lack of better word, 'the beauty of art', is that within a political work, you can disguise it as something beautiful. Maybe that's, when we get into the discussion of mana and kaona, I was just thinking about it, the work that I do with the maka is taking the stamen of the flower as the ule, as the male essence, but disguising it in a flower. So I have these compositions that are just full of ule, but then how many people are going to recognize that? They're just going to see it as a flower. But if I was to just make it very blatantly obvious that these components of the flower were actual penises, then are they gonna be turned off by it, or are they going to see it as something other? So [laughing], to each his own! [More laughter.]

But I like to think that following in the, I guess the whole [pause] 'tradition', or the 'aha-that lineage, link, that cord-back to our ancestors and to the future, that having art that's purposeful is part of our traditions of the things that we made were of purpose.

5 Slightly modified from its original form, which appears in Tengan (2014b). 


\section{'Aha moments and open-endings}

I end with a final note on the significance of the term 'aha that Pao spoke of, and some of its kaona. Describing the Ku image from the British Museum, Kalamakūloa (2011a) writes, 'The hair echoes the fruit spray of young coconut, and descend into 'aha, knotted cords, an allusion to prayers and numbering in fours and tens' (Location 247). As given in the Hawaiian Dictionary, some of the broader definitions of 'aha include:

1. n. Meeting, assembly, gathering, convention ... 2. nvi. Sennit; cord braided of coconut husk, human hair, intestines of animals; string for a musical instrument; to stretch the 'aha cord for the outline of a house so that the posts may be properly placed; measurement of an edge or border ... 3. n. A prayer or service whose efficacy depended upon recitation under taboo and without interruption. The priest was said to carry a cord ('aha) ... 4. n. Millipede, so called because it coils itself up like a string. 5. n. Any of the needlefishes of the family Belonidae ... 6. n. Design supposed to resemble the continuing track of a duck, carved on tapa beaters. (Pukui and Elbert 1986: 5)

Its first set of meanings includes conferences, such as in 'Aha Kāne Men's Conference; the second and third entries have received the most anthropological attention, especially in reference to ceremonies that were done on temples with Kü images during the 'aikapu period. Shore (1989: 152-53) and Valeri (1985: 295-308) have noted the significance of the 'aha as both symbol and container of divine mana, organising and binding the generative power of the gods to chiefs who are genealogically descended from them. Tēvita Ka'ili, Rochelle Fonotī and I have argued for a renewed attention to the role that 'aha, with all of its kaona, could play in forging new genealogies for Indigenous anthropology in Oceania, including the debates over and production of mana in anthropological gatherings (Tengan, Ka'ili and Fonoti 2010), such as the two that produced this volume (see Introduction). Drawing from my experiences with E Kū Ana Ka Paia and Remasculation, I suggest that some of the strained relations between Indigenous communities, anthropologists and museums might be overcome by establishing a shared commitment to building mana through an emphasis on ceremonial practice, genealogical reckoning, and creating new gathering spaces for the community. 
I do this, though, with hesitant and cautious hope. As Clifford notes: 'A symptomatic critique of heritage work may see it as occupying a comfortable niche in postmodern "multicultural" hegemonies: every identity gets its exhibition, website, coffee-table book, or film' (2013: 259). He responds:

The old/new articulations, performances, and translations of identity are not enough to bring about structural socioeconomic change. But they reflect and to a real extent create new conditions for indigenous solidarity, activism, and participation in diverse public spheres. When they are understood as part of a wider politics of selfdetermination, heritage projects are open ended in their significance. (Clifford 2013: 259)

Taking this approach, I would explore the suggestive aspects of Mary Kawena Pukui and Samuel H. Elbert's definition of 'aha as 'to stretch the 'aha cord for the outline of a house so that the posts may be properly placed', and their example of 'E ki'i $i$ ke kaula e 'aha ai, get a cord to stake out the house with' (1986: 5). Here we might think of 'aha as the practice of actively retrieving (ki'i), stretching, and loosening the bounds of tradition and heritage in a process of gauging connections, negotiating relationships, and resetting borders in the present so that structures in, of, and on our future homes will be pono-proper and in balance. Such an approach is even more important when addressing the challenges that arise when Indigenous genealogical lines clash and compete over the mana of anthropology or the museum, which was clearly the case in the Kawaihae struggle. While time and space do not permit me to explore the implications of 'aha praxis much further, I would suggest that in order for it to be effective - to have manait must articulate (Clifford 2013: 60-62) powerful linkages that allow people to see what was once unseen and imagine new possibilities and potential ways of being. These would be instantiated in what Carl F.K. Pao calls 'aha moments:

Like they say, you know, one of the recent expressions or whatevers is 'aha moments.' Well, I think of it as 'aha, not 'aha!' It's not, you're going, 'Ah, I turned the light on.' It's 'Ah, I made that link. I reconnected.' That's how I see it. And now I can, yeah, that link will continue. (Pao 2014b)

For veterans like Thomas Kaulukukui and Billy Richards, the 'aha moment came when they realised the mana of Kū was in their 'DNA'. While the future of Kānaka 'Ōiwi men and women may be open- 
ended, Kū has empowered a sense of agency and continuity in those who have engaged him. As one anonymous comment left at the Bishop Museum proclaimed: 'PAST, PRESENT + FUTURE ... KU IS A PART OF HAWAI'I, ITS PEOPLE AND OUR MANA!'

\section{Acknowledgements}

I would like to thank Noelle Kahanu, Carl F.K. Pao, Kalamakūloa and Matt Tomlinson for their comments on and assistance with this chapter. All mistakes are mine.

\section{References}

Bishop Museum. 2010. Annual Report. Online: www.bishopmuseum. org/images/pdf/annual_report.pdf, (accessed 2 November 2010).

Clark, Herman Pi'ikea. 2006. Kūkulu Kauhale o Limaloa: A Kanaka Maoli Culture Based Approach to Education through Visual Studies. D.Ed. dissertation, College of Education, Massey University.

- 2011. Ka Muhe'e, He I'a Hololua: Kanaka Maoli Art and the challenge of the global market. In Globalization and Contemporary Art, ed. Jonathan Harris, pp.137-46. West Sussex: Wiley-Blackwell.

Clifford, James. 2013. Returns: Becoming Indigenous in the Twenty-First Century. Cambridge, MA: Harvard University Press.

Dawrs, Stu. 2011. Regarding Ku. Hana Hou! The Magazine of Hawaiian Airlines 14(1) (February-March). Online: www.hanahou. $\mathrm{com} /$ pages $/$ Magazine.asp? Action $=$ Draw Article $\&$ ArticleID $=945 \&$ MagazineID $=60$ (accessed 7 October 2015).

Ellis, William. 1825. A Journal of a Tour around Hawaii, the Largest of the Sandwich Islands. New York: Crocker and Brewster.

Enomoto, Kekoa. 2010. Hawaiian homecoming. 'Unprecedented' exhibit reunites trio of ancient Hawaiian artifacts. The Maui News. 27 June. Online: www.mauinews.com/page/content.detail/ id/532814.html?nav=12 (accessed 7 October 2015). 
Ganaden, Sonny. 2014. The Last Statues of Kū. Flux Hawaii (Winter). Online: fluxhawaii.com/the-last-statues-of-ku/ (accessed 25 March 2016).

Gee, Pat. 2010. Gathering of the Gods. Honolulu Star-Bulletin. 4 June. Online: archives.starbulletin.com/content/20100604_Gathering_ of_the_gods (accessed 9 October 2015).

Goodyear-Kaopua, Noelani, Ikaika Hussey and Erin Kahunawaika'ala Wright (eds). 2014. A Nation Rising: Hawaiian Movements for Life, Land, and Sovereignty. Durham: Duke University Press.

Grace, Shantelle. 2010. Farewell, for now. Honolulu Weekly. 22 September. Online: honoluluweekly.com/cover/2010/09/farewellfor-now/ (accessed 7 October 2015).

Graham, Laura R. and H. Glenn Penny (eds). 2014. Performing Indigeneity: Global Histories and Contemporary Experiences. Lincoln: University of Nebraska Press.

Harris, Jonathan (ed.). 2011. Globalization and Contemporary Art. West Sussex: Wiley-Blackwell.

Howard, Alan and Robert Borofsky (eds). 1989. Developments in Polynesian Ethnology. Honolulu: University of Hawai'i Press.

Hyden, Amber-Lynn. 2010. Ku images come home. KITV News, 21 May. Online: www.youtube.com/watch?v=T27mhe0Sxz8 (accessed 2 November 2010).

Innes, Robert Alexander and Kim Anderson (eds). 2015. Indigenous Men and Masculinities: Legacies, Identities, Regeneration. Winnipeg: University of Manitoba Press.

Jolly, Margaret. 2008. Moving masculinities: Memories and bodies across Oceania. The Contemporary Pacific 20(1): 1-24.

2011. Becoming a 'new' museum? Contesting Oceanic visions at Musée du Quai Branly. The Contemporary Pacific 23(1): 108-39. 
Johnson, Greg. 2011. Courting culture: Unexpected relationships between religion and law in contemporary Hawai'i. In After Secular Law, ed. Winnifred Fallers Sullivan, Robert A. Yelle and Mateo Taussig-Rubbo, pp. 282-301. Stanford, CA: Stanford University Press.

Kahanu, Noelle. 2010. Interview on 'Bishop Museum' program of Nā 'Ōiwi 'Ōlino Radio Program. Office of Hawaiian Affairs. Online: www.naoiwiolino.com/?p=330 (accessed 2 November 2012).

—. 2012. Lecture in ANTH/ES 486 Peoples of Hawai'i class, University of Hawai'i at Mānoa. 6 March.

Kalama Productions Inc. 2010-11. moku mana. Website. Online: www. mokumana.com/MANA/Aloha.html (accessed 6 October 2015).

Kalamakūloa (David H. Kalama Jr). 201 la. Ki'i Akua - 54 Nights with $K \bar{u}$. Kindle Ebook. Online: www.amazon.com/Kii-Akua-NightsKÃ \%C2\%BC-Noeau-ebook/dp/B004INHXEQ/ref=sr_1_1?ie=UTF $8 \&$ qid $=1444305387 \&$ sr $=8-1 \&$ keywords $=54+$ nights + ku (accessed 9 October 2015).

_. 2011b. Ki'i Akua - 54 Nights with Kū. Online: www.youtube. com/watch? $\mathrm{v}=$ CmopShft128 (accessed 13 October 2014).

Kaulukukui, Thomas Ka'auwai Jr. 2012. Interview with author, Honolulu. 24 September.

Marshall, Wende Elizabeth. 2011. Potent Mana: Lessons in Power and Healing. Albany, NY: SUNY Press.

McDougall, Brandy Nālani. 2014. Putting feathers on our words: Kaona as a decolonial aesthetic practice in Hawaiian literature. Decolonization: Indigeneity, Education \& Society 3(1): 1-22.

Morgensen, Scott Lauria. 2011. Review: Making Space for Indigenous Feminism, J. Green (Zed Books, 2007); Native Americans and the Christian Right, A. Smith (Duke University Press, 2008); Native Men Remade, T. Tengan (Duke University Press, 2008); Mapping the Americas, S. Huhndorf (Cornell University Press, 2009). Signs: Journal of Women in Culture and Society 36(3): 766-76.

Nunes, Keone. 2010. Remarks at 'Nā Maka o Kū' Panel Discussion. Audio recording made by Geoffrey White. 4 June. 
Nākānelua, Kyle. 2010. Mo'olelo Huaka'i o Ku Ki'i. Unpublished manuscript.

Pao, Carl F.K. 2014a. Artist Statement. Posted at Pewa II: Remasculation and Human Seed Ships show at SPF Projects, Honolulu, 8 May 8 June.

- 2014b. Interview by author in Honolulu. 9 October.

Peabody Essex Museum (PEM). 2010. He's back! Kū returns amid honors from Hawaiian delegation. Online: www.pem.org/aux/pdf/ collection/KuSmall.pdf (accessed 2 November 2012).

Pukui, Mary Kawena and Samuel H. Elbert. 1986. Hawaiian Dictionary, revised and enlarged. Honolulu: University of Hawai'i Press.

Pukui, Mary Kawena with Laura C.S. Green. 1995. Folktales of Hawai ' $i$ : He Mau Ka'ao Hawai'i. Honolulu: Bishop Museum Press.

Richards, William Kahalepuna. 2012. Interview by author in Honolulu. 21 September.

Sahlins, Marshall. 1981. Historical Metaphors and Mythical Realities: Structure in the Early History of the Sandwich Islands Kingdom. Ann Arbor: University of Michigan Press.

Shore, Bradd. 1989. Mana and Tapu. In Developments in Polynesian Ethnology, ed. Alan Howard and Robert Borofsky, pp. 137-73. Honolulu: University of Hawai'i Press.

Sullivan, Winnifred Fallers, Robert A. Yelle and Mateo TaussigRubbo (eds). 2011. After Secular Law. Stanford, CA: Stanford University Press.

Tengan, Ty P. Kāwika. 2008. Native Men Remade: Gender and Nation in Contemporary Hawai'i. Durham: Duke University Press.

- 2014a. Portrait: Sam Kaha'i Ka'ai. In A Nation Rising: Hawaiian Movements for Life, Land, and Sovereignty, ed. Noelani Goodyear-Kaopua, Ikaika Hussey and Erin Kahunawaika'ala Wright, pp. 115-23. Durham: Duke University Press. 
2014b. The return of Kū? Re-membering Hawaiian masculinity, warriorhood, and nation. In Performing Indigeneity: Global Histories and Contemporary Experiences, ed. Laura R. Graham and H. Glenn Penny, pp. 206-46. Lincoln: University of Nebraska Press.

— 2015. The face of Kū: A dialogue on Hawaiian warriorhood with Thomas Ka'auwai Kaulukukui Jr and William Kahalepuna Richards Jr. In Indigenous Men and Masculinities: Legacies, Identities, Regeneration, ed. Robert Alexander Innes and Kim Anderson, pp. 231-44. Winnipeg: University of Manitoba Press.

Tengan, Ty P. Kāwika and Lamakū Mikahala Roy. 2014. 'I search for the channel made fragrant by the Maile': Genealogies of discontent and hope. Oceania 84(3): 315-30.

Tengan, Ty P. Kāwika, Tēvita O. Ka'ili and Rochelle Tuitagava'a Fonoti. 2010. Genealogies: Articulating Indigenous anthropology in/of Oceania. Pacific Studies 33(2/3): 139-67.

Valeri, Valerio. 1985. Kingship and Sacrifice: Ritual and Society in Ancient Hawai' $i$, trans. Paula Wissing. Chicago: University of Chicago Press.

Villanueva, Zach. 2010. Kū exhibit inspires tears, smiles, awe. Ka Wai Ola: The Living Water 27(12): 13.

White, Geoffrey. 2010. Museum mediations: Reflections on cultural politics at the Bishop Museum and the Musée du Quai Branly. Paper prepared for conference on 'Framing Cultures' Marseille: Centre de Recherche et de Documentation sur l'Océanie, Université de Provence, 5-6 November. 
This text is taken from New Mana: Transformations of a Classic Concept in Pacific Languages and Cultures, edited by Matt Tomlinson and Ty P. Kāwika Tengan, published 2016 by ANU Press, The Australian National University, Canberra, Australia. 